\title{
Injuries sustained after falls from bridges across the United States-Mexico border at EI Paso
}

\author{
Susan F. McLean ${ }^{1}$ and Alan H. Tyroch ${ }^{1}$
}

Suggested citation McLean SF, Tyroch AH. Injuries sustained after falls from bridges across the United States-Mexico border at El Paso. Rev Panam Salud Publica. 2012;31(5):427-34.

\begin{abstract}
Objective. To compare demographics and motivations for falls from bridges at the United States-Mexico border and in El Paso County, Texas, and to analyze injuries and injury patterns to support intentionality and to provide treatment recommendations.

Methods. A retrospective observational review was conducted of hospital admissions to a trauma center after falls from bridges from 1995 to 2009. Statistical methods used were chisquare testing, T-test for means comparison, univariate correlations, and regression analysis. Results. Of the 97 evaluated patients, $81.4 \%$ fell from U.S.-Mexico border bridges, including one patient who fell from a railway bridge; $74.7 \%$ of those falling from border bridges had a non-U.S. address, contrasting with $22.2 \%$ of those who fell within the United States. Falls over the border were associated with more immigration-related motivations and fewer suicide attempts. Injuries included lower extremities in 76 (78.4\%) and thoracolumbar spine in 27 (27.8\%) patients; 16 patients with a thoracolumbar spine fracture $(59.3 \%)$ also had a lower extremity injury. Mean hospital length of stay was 7.2 days. Mean injury severity score was 8.45 (range 1-43). Age, injury severity score, and pelvic fracture increased the hospital length of stay.

Conclusions. Patients fell while emigrating-immigrating based on residence and motivating factors. A dyad of lower extremity and thoracolumbar spine injuries coincided in $59.3 \%$ of those with a thoracolumbar spine injury; thoracolumbar spine imaging of patients evaluated after falls from bridges is recommended. Proposed prevention strategies include posting signs on bridges and installing catch-net safety barriers.
\end{abstract}

Key words Spinal fractures; brain injuries; emigration and immigration; accidental falls; border health; United States; Mexico.

Historically, people have emigrated into the United States of America across the southwestern border, often incurring injury. The U.S. Government Accountability Office (GAO) has reported on deaths that occur during emigration and immigration (1). While apprehensions of immigrants along the southwestern U.S.

\footnotetext{
1 Department of Surgery, Texas Tech University Health Sciences Center, El Paso, Texas, United States of America. Send correspondence to: Susan F. McLean, susan.mclean@ttuhsc.edu
}

border have decreased slightly, from 1516680 in 1998 to 1139282 in 2004, immigration-related mortality has increased, from 241 in 1999 to 472 in 2005 (2). This rise was attributed to increased staffing of law enforcement at border crossing sites, which encouraged migrants to cross the Sonora Desert. By 2003, the major cause of border crossing death was environmental exposure; before 1990, motor vehicle crashes were the major cause of death (3). These reports did not mention falls as a reason for border crossing injury and death.

El Paso, a U.S. city in Texas, abuts the Mexican border at Ciudad Juarez in the Mexican state of Chihuahua. The border includes bridges over the Rio Grande River (3). Traffic across the bridges from Ciudad Juarez, Mexico, into El Paso, Texas, has increased over the past two decades. In 1997, there were 12.6 million automobile crossings northbound into Texas at El Paso, increasing to 13.2 
million vehicles in 2008 (4). The U.S. Department of Transportation, Bureau of Transportation Statistics, Research and Innovative Technology Administration reported that in 1995 there were 4403325 pedestrians entering at $\mathrm{El}$ Paso; the number increased to 8029106 in 2008 (5). Increasing traffic provides greater opportunity for falls.

Border crossings may be economically motivated. Data from the U.S.-Mexico Border Health Commission, derived from the 2000 Mexican census, show that of the six Mexican border states, Chihuahua had the highest percentage of persons living at or below the poverty level, at $46.1 \%$ of the population (6). If seeking economic improvement is a motivator for immigration, then immigration from the poorest state on the Mexican border would be expected to occur. Routes of immigration from Mexico near El Paso involve crossing the Rio Grande River on bridges; if facing capture, an immigrant's only escape is often off the bridge. This cause is not listed in the GAO report, except as "other" (1). Intentional falls are a potentially preventable cause of morbidity and mortality. This study evaluates falls from bridges crossing the U.S.-Mexico border at El Paso to determine likely causality and to analyze injuries. If falls are deemed likely intentional, which differ from accidental falls, then a prevention strategy can be constructed.

The first hypothesis is that reasons for falls will be different and will be more emigration-immigration related for over-border falls than for in-county falls. Residency locations will also differ: over-border falls will more likely be associated with non-U.S. citizens, leading to a conclusion of likely intentionality.

The second hypothesis is that there will be more lower extremity injuries and more injuries indicating feet-first landings in over-border falls. Feet-first landing patterns, associated with intentionality, lead to more lower extremity injuries and more thoracolumbar spine injuries and fewer upper extremity and intracranial injuries. This pattern will support the first hypothesis-that most falls from border bridges are intentional.

\section{MATERIALS AND METHODS}

This study is a retrospective observational study of patients admitted to the University Medical Center of El Paso after falls from international bridges con- necting Mexico to El Paso, Texas. Specific bridges noted by patients and law enforcement were: Paso Del Norte International Bridge, the Bridge of the Americas, and the Ysleta-Zaragoza Bridge. Trauma registry data and medical records from 1995 through 2009 were reviewed for location, demographics, injuries, intoxicants, treatment, and outcomes. The injury severity score used in this study utilizes scoring tables to rate injuries by severity, takes the highest score for each of six body areas, uses the top three and squares them, and then sums them. The injury severity score can range from 1 to 75 ; a score of 15 is considered critical injury. The injury severity score was calculated by Collector for Windows, version 3.30 (Digital Innovations Incorporated, 1987-2002). Hospital length of stay and intensive care unit length of stay were recorded. Reasons for falls were gleaned from reading the patient history, consultations, and social workers' notes. Residency was assigned by using the registration address. For statistical analyses, group means were compared by $T$-test, and categorical variables were compared by chi-square testing. Pearson's correlations were used for univariate data, and linear forward stepwise regression analysis was used to evaluate multivariate analysis variables, which were found to correlate significantly in univariate analysis. Statistical Package for the Social Sciences (SPSS), version 18.0, was used for statistical analysis. The University Medical Center of El Paso and Texas Tech University combined Institutional Review Board for Ethical Research for Human Subjects approved the study before initiation. This committee waived consent because of retrospective chart re-

TABLE 1. Patients' reasons for falls from bridges at U.S.-Mexico border and in El Paso County, Texas, 1995-2009

\begin{tabular}{lccc}
\hline & \multicolumn{3}{c}{ Number of patients } \\
\cline { 2 - 4 } \multicolumn{1}{c}{ Reason for falling from bridge } & $\begin{array}{c}\text { Over border } \\
(n=79)\end{array}$ & $\begin{array}{c}\text { In county } \\
(n=18)\end{array}$ & $\begin{array}{c}\text { Total } \\
(n=97)\end{array}$ \\
\hline Being chased by border patrol & 24 & 0 & 24 \\
Trying to cross illegally & 25 & 1 & 26 \\
Suicide attempt & 3 & 6 & 9 \\
No reason & 24 & 3 & 2 \\
Avoiding assault & 2 & 0 & 1 \\
Avoiding being hit by car & 0 & 1 & 4 \\
Running from police & 1 & 3 & 1 \\
Trying to stop someone else from jumping & 0 & 1 & 2 \\
Trying to jump over overpass bridge & 0 & 2 & 1 \\
Urinating off high bridge & 0 & 1 & 2
\end{tabular}

Note: Over-border falls had immigration-emigration-related reasons and fewer suicide attempts than in-county falls; numbers are statistically significant by chi-square testing. Categories with one or two responses were collapsed for chi-square testing. view study and blinding of patient identification during research and publication.

\section{RESULTS}

There were 97 patients: 81 males and 16 females. Mean age was 31 years (range 13-77). Seventy-nine $(81.4 \%)$ patients in this report fell from a bridge, including railway bridges, spanning the U.S.-Mexico border across the Rio Grande River. The International Boundary and Water Commission, U.S. section, lists bridge heights as 9.8-10.8 meters above ground, depending on bridge and location (personal communication, 18 March 2012). Eighteen patients fell from a highway bridge at least a half mile from the border. March was the most common month for bridge falls (7), followed by July (8) and August (9).

Motivating reasons for the entire group included: self-reported immigration: $26(26.8 \%)$, border patrol pursuit: $24(24.7 \%)$, suicide attempt: $9(9.2 \%)$, evading police: $3(3.0 \%)$, avoiding assault: $2(2.1 \%)$, and various other reasons. Twenty-seven patients did not indicate why they fell. Location analysis shows that $81.4 \%$ (79 persons) fell from a bridge spanning the U.S.-Mexico border; others fell from in-county bridges. The 79 patients who fell directly across the border stated the following reasons: 25 were attempting immigration, 24 were actively chased by border patrol officials, 24 stated "no reason," 3 were attempting suicide, 2 were avoiding assault, and 1 was running from police (Table 1). Among the 18 patients who fell from a bridge in the county, 10 gave the following reasons: 1 was attempting 
TABLE 2. Fractures of lower extremity in patients who fell from bridges at U.S.-Mexico border and in El Paso County, Texas, 1995-2009

\begin{tabular}{|c|c|c|c|}
\hline \multirow[b]{2}{*}{ Fracture site } & \multicolumn{3}{|c|}{ Number of fractures } \\
\hline & Open ${ }^{a}$ & Closed $^{b}$ & Total \\
\hline Femur & 1 & 12 & 13 \\
\hline Tibia and fibula & 17 & 34 & 51 \\
\hline Ankle & 3 & 32 & 35 \\
\hline Calcaneous $^{\mathrm{C}}$ & 2 & 20 & 22 \\
\hline Foot & 1 & 12 & 13 \\
\hline
\end{tabular}

a Fractures in which overlying skin is open or lacerated.

b Fractures have intact skin overlying them.

c Refers to heel bone.

immigration, 6 were attempting suicide, and 3 stated "no reason" for their fall; compared with over-border bridge falls, these reasons were significantly different $(P<0.001)$.

Registration addresses showed that $59 / 79$ or $74.7 \%$ of those who fell directly over the border gave a permanent residence address as not in the United States, while $4 / 18$ or $22.2 \%$ of those who fell inside El Paso county gave a non-U.S. address, including "general delivery." This difference was significant (chi-square test, $P<0.001$; Somer's $D$ directional measures show country of residence as $0.438, P=0.002)$. One person who fell in the county admitted to just having immigrated but had an intentional fall from a highway bridge, not the actual border bridge, and was counted as an immigrant.

\section{Injury severity}

The mean injury severity score was 8.5 (range 1-43). Sixteen (16.5\%) patients had an injury severity score $\geq 15$. One patient died of a myocardial infarction after a fall inside the United States.

Sixty-one $(62.9 \%)$ patients had toxicology testing, and 32 of them $(52.4 \%$ of those tested, or $32.9 \%$ of total) were positive. Thus, a minority of patients were intoxicated. The mean injury severity score for intoxicant-positive patients was 10.4 and the mean injury severity score for intoxicant-negative patients was 8.7 (not significant). The most common intoxicant was ethanol, followed by cocaine.

\section{Injuries and treatment}

Lower extremity. The most common injuries were lower extremity injuries, found in 76 patients $(78.4 \%)$. Tibia and fibula injuries were the most frequent with 51 total fractures and their repair was the most common operation (Table 2).

Thoracic and lumbar vertebral fractures. Thoracolumbar spine fractures and operations are summarized in Table 3. Twenty-seven patients had a thoracolumbar vertebral spine fracture; 11 of them had multiple vertebral levels. Four patients with a thoracolumbar spine fracture had neurologic deficitsone partial and one with cauda equina compression with minimal symptoms. Of the 27 patients with a thoracolumbar vertebral fracture, 6 had surgery. Most thoracolumbar fractures were junction fractures, with 21 of 27 having either thoracic vertebrae 11 or 12 or lumbar level 1 or 2 (Table 3 ).

A dyad of thoracolumbar spine fracture and lower extremity injury occurred in $16 / 27$ or $59.3 \%$ of spinal fracture patients (Table 3). Twenty-one percent of patients with a lower extremity injury also had a thoracolumbar spine fracture. The relative risk of having a thoracolumbar spine injury if presenting with a lower extremity injury, compared with patients with intact lower extremities, was 1.45 (Fischer's exact test, $P=0.011$, two sided; confidence interval $=1.04$ 2.01). The relative risk of having a lower extremity injury if presenting with a thoracolumbar injury, compared with those with an intact thoracolumbar spine, was 2.49 (Fischer's exact test, $P=0.011$, two sided, confidence interval $=1.37-4.52$ ).

Twenty-four patients (88.8\%) with a thoracolumbar spine injury fell from a border bridge. One other patient with a thoracolumbar fracture fell from a highway bridge near the border and gave as citizenship "Mexico." Among the 27 patients with a thoracolumbar vertebral spinal fracture, 10 of the $18(55.5 \%)$ who were screened tested positive for intoxicants.

Other areas. Brain injuries are indicated in Table 4. Less frequent injuries included upper extremities, facial bones, pelvis, and torso. Fifteen patients had upper extremity injuries (Table 5). Other injured body areas are shown in Table 6 . All six major body areas were injured.

\section{Hospital length of stay}

Mean hospital length of stay was 7.2 days (range 1-81). Eighteen patients were admitted to the intensive care unit; mean intensive care unit length of stay was 11.3 days, and median was 4.5 days. For patients who went to the intensive care unit, mean hospital length of stay was longer at 16.5 days. Length of stay did not differ significantly in intoxicated and nonintoxicated patients (6.3 days for intoxicated patients and 7.9 days for nonintoxicated patients). Age, injury severity score, and pelvic fracture were significantly correlated univariately with an increased length of stay $(P<0.01)$. When examined in a linear regression model, age, injury severity score, and presence of a pelvic fracture remained significant predictors of length of stay $\left(P=0.000, R^{2}=29 \%\right)$.

\section{DISCUSSION}

This study examined falls from U.S.Mexico border area bridges. Many falls were likely intentional attempts at immigration; a majority of border-crossing falls were associated with an address outside the United States and had different reasons for falls than those who fell inside the United States (the numbers 
TABLE 3. Thoracic and lumbar vertebral fractures along with lower extremity fractures showing the dyad of thoracic and lumbar vertebral fractures and lower extremity fractures in patients who fell from bridges at U.S.-Mexico border and in El Paso County, Texas, 1995-2009

\begin{tabular}{|c|c|c|c|c|}
\hline $\begin{array}{c}\text { Case } \\
\text { deidentified }\end{array}$ & TL spine description & $\begin{array}{l}\text { Neuro- } \\
\text { deficit }\end{array}$ & LE fracture description & TL surgery \\
\hline 1 & $\begin{array}{l}\text { Thoracic spine closed } \\
T 12^{\mathrm{a}} \text { compression }^{\mathrm{b}} \mathrm{fx}\end{array}$ & No & & No \\
\hline 2 & $\begin{array}{l}\text { Lumbar spine closed } \\
\text { Burst }^{\mathrm{b}} \text { fx L1 } \\
\text { Partial paraplegia }\end{array}$ & Yes & $\begin{array}{l}\text { Comminuted }^{c} \\
\text { Femur } \mathrm{fx} \\
\text { Left Tib-fib fx } \\
\text { Left distal Tib-fib fx } \\
\text { Open tibia fx }\end{array}$ & 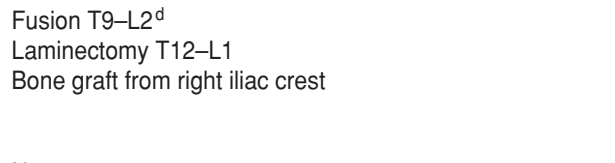 \\
\hline 3 & Lumbar spine closed L3 wedge compression & No & & No \\
\hline 4 & Lumbar spine closed L1 compression fx & No & $\begin{array}{l}\text { Left distal Tib-fib fx } \\
\text { Ankle medial malleolar }\end{array}$ & No \\
\hline 5 & Lumbar spine closed L1 burst fx & No & & No \\
\hline 6 & $\begin{array}{l}\text { Lumbar spine } \\
\text { Lumbar spine } \\
\text { L2 compression } \mathrm{fx} \\
\text { L5 compression } \mathrm{fx}\end{array}$ & No & $\begin{array}{l}\text { Ankle bimalleolar } \\
\text { Comminuted right distal tibia }\end{array}$ & \\
\hline 7 & $\begin{array}{l}\text { L1 compression } \mathrm{fx} \\
\mathrm{L} 2 \text { compression } \mathrm{fx} \text { end plate }\end{array}$ & No & $\begin{array}{l}\text { Ankle trimalleolar } \\
\text { Right ankle fracture }\end{array}$ & No \\
\hline 8 & L1 and L3 compression fx & No & & No \\
\hline 9 & $\mathrm{~T} 11$ and $\mathrm{T} 12$ compression $\mathrm{fx}$ & No & $\begin{array}{l}\text { Tib-fib fracture } \\
\text { Left open tibia fx, comminuted }\end{array}$ & No \\
\hline 10 & $\begin{array}{l}\text { L1 compression } f x \\
\text { Right } L 1 \text { lamina }^{\dagger} f x\end{array}$ & Yes & & $\begin{array}{l}\text { Yes } \\
\text { L1 corpectomy, T12-L1 discectomy, fusion T12-L1 }\end{array}$ \\
\hline 11 & T12 and L1 compression fx & No & $\begin{array}{l}\text { Tib-fib fx open } \\
\text { Grade IIIA right. Tibia fx } 9 \\
\text { Right great toe dislocation }\end{array}$ & No \\
\hline 12 & L2 burst $f x$ & No & & $\begin{array}{l}\text { Yes } \\
\text { Open reduction internal fixation, post-spinal fusion T12-L3 }\end{array}$ \\
\hline 13 & L1 compression fx & No & $\begin{array}{l}\text { Ankle trimalleolar } \\
\text { Left tibia fx }\end{array}$ & \\
\hline 14 & $\begin{array}{l}\text { T12 compression } \mathrm{fx} \\
\mathrm{L} 2 \text { and } \mathrm{L} 4 \text { compression } \mathrm{fx} \text { closed }\end{array}$ & No & Right knee ACL ligament disruption & No \\
\hline 15 & $\begin{array}{l}\text { T12 lamina } \mathrm{fx} \\
\mathrm{L} 1, \mathrm{~L} 2, \mathrm{~L} 3 \text { compression } \mathrm{fx}\end{array}$ & No & $\begin{array}{l}\text { Ankle trimalleolar closed } \\
\text { Ankle bimalleolar closed } \\
\text { Right distal tibia plafond fx } \\
\text { Left talus fx }\end{array}$ & No \\
\hline 16 & T1 lamina fx & No & & No \\
\hline 17 & L4 burst fx & No & & No \\
\hline 18 & L3 compression $\mathrm{fx}$ & No & $\begin{array}{l}\text { Femur fx } \\
\text { Ankle medial malleolar closed } \\
\text { Tib-fib upper closed } \\
\text { Intertrochanteric femur closed }\end{array}$ & \\
\hline 19 & L2 burst $f x$ & No & & \\
\hline 20 & $\begin{array}{l}\text { L4 anterior column compression } \mathrm{fx} \\
\mathrm{L} 5 \text { anterior column compression } \mathrm{fx}\end{array}$ & No & & \\
\hline 21 & T12 compression $\mathrm{fx}$ & No & $\begin{array}{l}\text { Open calcaneal }{ }^{h} \mathrm{fx} \\
\text { Navicular }^{\mathrm{i}} \mathrm{fx} \\
\text { Talus } \mathrm{fx}\end{array}$ & \\
\hline 22 & L1 compression $\mathrm{fx}$ & No & Bilateral calcaneous $f x$ & \\
\hline 23 & L3 comminuted burst fx & Yes & $\begin{array}{l}\text { Tibia fx upper } \\
\text { Astragalus } \mathrm{fx} \\
\text { Pilon and talus } \mathrm{fx}\end{array}$ & $\begin{array}{l}\text { L3 corpectomy } \\
\text { Fusion L2-L4 }\end{array}$ \\
\hline 24 & $\begin{array}{l}\text { L2 burst } f x \\
\text { T11 end plate } f^{\text {compression }}\end{array}$ & No & Calcaneal fx & \\
\hline 25 & L2 compression fx endplate & No & $\begin{array}{l}\text { 2nd metatarsal' fx } \\
\text { Tibia fx }\end{array}$ & \\
\hline 26 & L1 burst $f x$ & Yes & & $\begin{array}{l}\text { T12-L2 postspinal fusion } \\
\text { T12 laminectomy }\end{array}$ \\
\hline 27 & $\begin{array}{l}\text { L1 burst fx } \\
\text { L5 pedicle }\end{array}$ & No & $\begin{array}{l}\text { Femur } \mathrm{fx} \text {, shaft } \\
\text { Bilateral calcaneous }{ }^{h} \mathrm{fx}\end{array}$ & T12-L1 posterior fusion \\
\hline
\end{tabular}

Note: TL: thoracolumbar, LE: lower extremity, fx: fracture, Tib-fib: tibia and fibula, ACL: anterior cruciate ligament of the knee. Cases are in no specific order in order to protect patient identity.

a A designation of $T$ or $L$ followed by a number refers to thoracic vertebral level or lumbar vertebral level and a specific vertebra. Thus, T12 means thoracic vertebral level 12.

${ }^{b}$ Compression and burst refer to types of vertebral fractures. Compression refers to the cranial-caudal compressive forces causing the fracture, and burst means the pieces of the vertebral body have burst apart.

c Comminuted refers to a fracture in multiple parts.

d T9-L2 means thoracic level 9 vertebra through lumbar level 2 vertebra inclusive. This usually refers to fixation, where the fixation device bridges those vertebrae. If a patient has fractures from one level to another inclusive, this designation also applies.

e Trimalleolar and bimalleolar refer to parts of the ankle.

f Lamina, pedicle, and end plate are parts of the vertebra. Column refers to the integrity of the spine as a whole, involving more than one structure. Anterior columns are in front of the spinal cord, and posterior columns are behind it.

9 Grade IIIA refers to the orthopedic grading of ankle fractures. III is worse than I and II.

${ }^{\mathrm{h}}$ Calcaneal and calcaneous refer to heel bone.

i Navicular, talus, astragulus, and metatarsal are foot bones. 
TABLE 4. Brain injuries along with surgery in patients who fell from bridges at U.S.-Mexico border and in El Paso County, Texas, 1995-2009

\begin{tabular}{|c|c|c|c|}
\hline Case & Injury & Surgery & Comment \\
\hline 1 & $\begin{array}{l}\text { Bilateral skull fracture } \\
\text { Bilateral frontal contusions } \\
\text { Right temporal contusions } \\
\text { Epidural hematoma }\end{array}$ & $\begin{array}{l}\text { 1. Frontal craniotomy } \\
\text { 2. Bilateral frontal } \\
\text { decompressive craniectomy }\end{array}$ & $\begin{array}{l}\text { Cause of craniectomy was high } \\
\text { intracranial pressure }(>30)\end{array}$ \\
\hline 2 & $\begin{array}{l}\text { Bilateral frontal contusions } \\
\text { Multiple skull fractures }\end{array}$ & $\begin{array}{l}\text { 1. Bilateral frontal craniectomy } \\
\text { 2. Craniotomy with evacuation } \\
\text { of subdural hematomas }\end{array}$ & $\begin{array}{l}\text { Cause of craniectomy was high } \\
\text { intracranial pressure }(>30)\end{array}$ \\
\hline 3 & $\begin{array}{l}\text { Left temporal contusion } \\
\text { Depressed skull fracture }\end{array}$ & Insertion of ventriculostomy & $\begin{array}{l}\text { Coagulopathy and shock } \\
\text { state precluded elevation of } \\
\text { depressed skull fracture }\end{array}$ \\
\hline 4 & Subarachnoid hemorrhage & No surgery required & \\
\hline 5 & Subarachnoid hemorrhage & No surgery required & \\
\hline 6 & Basilar skull fracture & No surgery required & \\
\hline 7 & $\begin{array}{l}\text { Temporal epidural plus temporal } \\
\text { contusion }\end{array}$ & No surgery required & \\
\hline 8 & $\begin{array}{l}\text { Right occipital subdural } \\
\text { hematoma }\end{array}$ & No surgery required & \\
\hline
\end{tabular}

Note: Cases do not indicate a specific patient in the database; order is scrambled to protect identity.

TABLE 5. Other body area injuries sustained, excluding thoracolumbar spine and leg, in patients who fell from bridges at U.S.-Mexico border and in El Paso County, Texas, 1995-2009

\begin{tabular}{lcc}
\hline \multicolumn{1}{c}{ Body area } & Number of injuries & Comment \\
\hline $\begin{array}{l}\text { Upper extremity injuries } \\
\text { (shoulder, arm, hand) }\end{array}$ & 17 & $\begin{array}{c}\text { All but } 2 \text { injuries were below the elbow; } 5 \text { open wounds } \\
\text { were included with the } 12 \text { fractures }\end{array}$ \\
Craniofacial injuries & 16 & $\begin{array}{c}3 \text { maxilla fractures, } 3 \text { mandible fractures; the remainder } \\
\text { were contusions and lacerations }\end{array}$ \\
Pelvic fractures & 6 & $\begin{array}{c}3 \text { sacral fractures, } 1 \text { acetabular fracture, } 1 \text { pubis fracture, } 1 \\
\text { sacral dislocation }\end{array}$ \\
Cervical spine & 2 & $\begin{array}{c}\text { Vertebrae } 4 \text { and } 7 \\
\text { 3 pulmonary contusions, } 1 \text { lung laceration, } 2 \text { rib fractures, } 1 \\
\text { sternal fracture } \\
\text { 1hepatic and renal laceration, } 1 \text { iliac vein injury, } 1 \\
\text { abdominal compartment syndrome from resuscitation }\end{array}$ \\
Abdominal & 7 & 3
\end{tabular}

Note: These injuries encompass all the major body areas used in injury severity score calculations and show that, although thoracolumbar spine and lower extremity were the most common, all body areas had injuries requiring treatment.

TABLE 6. Billed hospital charges for patients who fell from bridges at U.S.-Mexico border and in El Paso County, Texas, 1995-2009

\begin{tabular}{lcccc}
\hline \multicolumn{1}{c}{ Group } & $\begin{array}{c}\text { Number } \\
\text { in group }\end{array}$ & $\begin{array}{c}\text { Number of } \\
\text { captured charges }\end{array}$ & $\begin{array}{c}\text { Mean charge } \\
\text { (U.S. dollars) }\end{array}$ & $\begin{array}{c}\text { Sum of all charges } \\
\text { in group } \\
\text { (U.S. dollars) }\end{array}$ \\
\hline $\begin{array}{l}\text { Total group } \\
\begin{array}{l}\text { Border crossers } \\
\text { Group reimbursement } \\
\text { data available }\end{array}\end{array}$ & 97 & 86 & 35778 & 3076877 \\
\hline
\end{tabular}

Note: Charges are rounded to nearest dollar. Thirty-two patients had charges filled.

were significantly different). Another finding was a large number of lower extremity injuries and a dyad of thoracolumbar vertebral fracture and lower extremity fracture; these injury clusters point to a feet-first landing, which likely is intentional (10). Factors that increased hospital length of stay included age, in- jury severity score, and the presence of a pelvic fracture.

According to patients' responses, it appeared that most patients fell while attempting to cross the border from Chihuahua, Mexico, including Ciudad Juarez south of El Paso, Texas, at the border over the Rio Grande River into the United States. Information from the U.S.-Mexico Border Health Commission indicates that the estimated total volume of border crossings into the United States at the northern border of Mexico is 310 million/year (9). According to the U.S.Mexico Border Health Commission, rates of persons living at or below the 
poverty level in the six northern Mexican states range from $12.4 \%$ to $46.1 \%$ (in Chihuahua) (11). In Chihuahua, only $23.7 \%$ of the population has higher than an elementary school education (8). The pervasiveness of poverty in the region may contribute to their motivation to emigrate north into the United States. Twenty-four patients in the study stated that they were attempting immigration and another 25 were noted to have been chased by U.S. border patrol agents. The remainder of the patients whose falls were deemed immigration related were noted to not be legal U.S. residents and fell from a border area bridge. The highest rate of border-related falls-in March, July, and August-may be related to increased job opportunities for migrants during planting and harvesting in the region, although this question was not specifically asked.

Most urban fall series list intoxication and suicidality as prime motivators $(7,12,13)$. In the Harlem Hospital series (12), the most common reasons for falls were accidents, suicide, crime, and undetermined; alcohol was present in one-third of the patients (12). In the Los Angeles County-University of Southern California study, intoxicants were associated with $59 \%$ of screened or $37.9 \%(71 / 187)$ of total falls, and $6.5 \%$ of falls were deemed intentional (7). In this, immigration was an apparent motivator: 79 patients had intentional falls directly over the border, and 1 patient who stated he was trying to immigrate fell from an in-county bridge. There were fewer intoxicant-motivated falls: $39 \%$ of those tested, or $29 \%$ of total. According to location of falls, border crossing falls had a higher incidence of immigrationrelated reasons and in-county falls had a higher incidence of suicide attempts.

Two factors affecting injury severity include height and position at landing. Fall height has been shown to correlate with injury severity and mortality $(7,14)$. Height is related to stopping distance or stopping time. Basically, a harder surface is associated with a shorter stopping time, and more force is generated and transmitted to the skeleton. Warner and Demling discussed the physics of free-fall injury in their report (15). According to newtonian physics, force at impact is equal to mass times acceleration. In a fall, acceleration is deceleration, which is the acceleration due to gravity. The quantity of deceleration is proportional to the gravitational constant and the height of the fall and inversely proportional to the stopping distance at impact. The stopping distance is determined by the physical properties of the material composing the surface upon which the person falls (15). For example, mud is softer than concrete and has a longer stopping distance and a longer stopping time. In addition, the energy transfer from the fall is governed by the equation $\mathrm{KE}=\mathrm{ME}+\mathrm{PE}+$ heat, where $\mathrm{KE}$ is kinetic energy, ME is mechanical energy, and PE is potential energy (15). On a hard surface with a short stopping time, most of the kinetic energy is converted into mechanical energy, which is transmitted to the patient's tissues. A softer surface with a longer stopping time yields less mechanical energy and hence less injury. This may explain the variability in injury severity score despite similar fall heights: some patients may have landed in mud instead of in water or on rocks, depending on the water level in the Rio Grande River.

Besides height and stopping distance, another factor that affects injuries is the position at landing, which in this study was likely a vertical position. Lowenstein et al. (10) discussed a series of 12 patients who landed on their feet after urban falls and reported lower extremity and thoracolumbar junction injuries. Our reported injury frequencies are similar to other series of urban free falls of 40 feet or less $(7,10,12,13)$. A Los Angeles County study of urban falls from heights was similar in that most of the falls were $<40$ feet, so it provides a good comparison group (7). In this study, fractures were the most common injury, with lower extremity fractures the most common at $71.0 \%$; in contrast, the Los Angeles County study indicated $37.4 \%$ of the total had extremity injuries, including upper extremity injuries (7). Most injuries in this series were lower extremity injuries (71.0\% of patients), followed by thoracolumbar spine fractures with few cervical spine and upper extremity fractures. In this study, as in the Los Angeles County series, the next most common injury site was the spinal column, with $27.0 \%$ of injuries in this study and $20 \%$ in the Los Angeles County series (7). In this study, there is a higher frequency of lower extremity fractures and then spinal column fractures; a subset of patients have both. Our data correlated with a series of patients who likely landed on their feet, with sec- ondary involvement of the upper body and head, as described in other series of falls with patients who were known to land on their feet $(7,10,12-14)$.

Fifty-nine percent of patients in this study with vertebral fractures had a thoracic or lumbar vertebral fracture plus a lower extremity fracture $(7,12-14$, $16,17)$. The spinal fracture rate in this study, 27/97 (27.8\%), was higher than the rate reported in the Los Angeles County-University of Southern California series, 37/187 (19.8\%) (7). Only one patient in this study had a spinal cord injury; the Los Angeles County series reported 3/37 (8.1\%) spinal fracture patients with a neurologic deficit (7). Scalea and colleagues reported 38/161 (23.6\%) patients with a spinal vertebral fracture in their series of urban falls and 11/38 (28.9\%) with a spinal cord injury (13). There was a $55.5 \%$ intoxication rate in tested patients with vertebral fractures in this study. Both intoxicants and pain from other injuries obscure spinal column exams in patients after falls $(15,16)$. In a study of 4142 patients admitted to a trauma center, major nonthoracolumbar injury and fall mechanism of injury were risks for thoracolumbar fracture $(P \leq$ 0.05) (15). A study of patients having thoracic and lumber radiographs after trauma found three factors associated with thoracolumbar spine injury: injury severity score $\geq 15$, positive physical exam, and fall $\geq 10$ feet (16). In a series of 200 falls with 40 vertebral fractures, calcaneus (heel) fractures were associated with vertebral fractures in $5 / 8$ patients (18). In this study, the relative risk of having a thoracolumbar spine fracture was significantly greater in patients who had lower extremity injuries than in patients who did not have a lower extremity fracture. Based on the injury dyad and the intoxication rate of $55.5 \%$, we recommend imaging the thoracolumbar spine after falls from bridges, especially in patients with lower extremity injuries.

The demographics in this series are similar to those in other fall series: the mean age in this study was 30.8 years; in the King's County series it was 31.7 years (13). The mean ages in other studies were similar: Boston, Massachusetts, 28.3 years and Harlem Hospital, New York, 23 years $(7,12,13)$. Those two series, like this one, also had a predominance of males. Increased age in our study was significantly associated with increased hospital length of stay. Neither 
age nor intoxicant use was associated with higher injury severity score; however, age, injury severity score, and presence of pelvic fracture led to increased hospital length of stay. The gender breakdown in this study (male:female ratio $81: 16=4.6: 1$ ) was similar to that in other studies; in Scalea's study it was 123:37 (3.3:1), and in the Harlem Hospital study it was 41:12 (3.4:1) $(12,13)$. In short, patients were primarily young males, in the productive stage of life. Preventing these injuries is necessary to prevent loss of function and missed work.

Prevention may be the most important factor in decreasing falls. The Golden Gate Bridge in San Francisco, California, has signs to abate suicide-related falls (19). A similar sign could be posted to warn of dangers at the border bridges. Another strategy is to construct catch nets to prevent injuries in people who fall, similar to the Jacques Cartier Bridge in Montreal, Quebec, Canada (20), after a case series of suicides were published (21). Laws have not decreased immigrant deaths at the U.S.-Mexico border; in fact, mortality has been on the rise since increased law enforcement at the border (1-3).

Potential weaknesses in this study include retrospective data collection. A prospective study with specific confidential interviews might elicit fall motivators from more patients. Residency was based on responses to the registrar. It is possible that some persons gave an incorrect address; also the registrar assigns "general delivery El Paso" for unconscious patients. The patient numbers were sufficient to show that lower extremity and thoracodorsal spine injuries were frequent and occur together. However, numbers were not high enough for other injuries to see secondary trends. The obtainable study population was patients admitted to the only level one trauma center in the region. Information could not be collected from patients who were pronounced dead at a bridge and not admitted.

\section{CONCLUSIONS}

This series of urban falls is unique in showing a previously undescribed mechanism of injury sustained while immigrating. We compared over-border falls with in-county falls for the reason given for the fall and the patient's stated residency and found that the two factors differed significantly. This indicates intentionality - that is, most persons falling over the border had findings consistent with attempting immigration as motivation for the fall.

Injuries were analyzed to make recommendations as well as support a hypothesis of intentional fall. Distinct patterns indicate that a feet-first landing after the fall is consistent with intentionality. The high incidence of lower extremity fractures and the lower extremity-thoracolumbar vertebral fracture dyad demonstrate that force generated from a feet-first landing was transmitted up through the spine. The relative risk of thoracolumbar spine fracture was significantly greater in patients who arrived with a lower extremity injury than in those who did not. Thoracolumbar spine imaging is recommended for patients who have fallen from bridges.

\section{REFERENCES}

1. Ekstrand, LE. Illegal immigration: border crossing deaths have doubled since 1995: border patrol's efforts to prevent deaths have not been fully evaluated. Washington, D.C.: GAO; 2006. P. 4.

2. Ekstrand, LE. Illegal immigration: border crossing deaths have doubled since 1995: border patrol's efforts to prevent deaths have not been fully evaluated. Washington, D.C.: GAO; 2006. P. 59.

3. Ekstrand, LE. Illegal immigration: border crossing deaths have doubled since 1995: border patrol's efforts to prevent deaths have not been fully evaluated. Washington, D.C.: GAO; 2006. P. 8.

4. Fullerton TM Jr, Molina AL Jr. Borderplex economic outlook: 2009-2011. Business Report SR09-2. El Paso, Texas: University of Texas at El Paso Border Region Modeling Project; 2009.

5. United States Border Health Commission. Health program for Mexico's northern border. El Paso, Texas: U.S. Border Health Commission; 2003. P. 27. Available from: http://www. borderhealth.org/ Accessed 20 December 2011.

6. U.S. Department of Transportation, Research and Innovative Technology Administration. Available from: http://www.transtats.bts.gov/Border Crossing.aspx Accessed 20 December 2011.

7. Velmahos GC, Demetriades D, Theodorou D, Cornwell EE III, Belzberg H, Asensio J, et al. Patterns of injury in victims of urban freefalls. World J Surg. 1997;21(8):816-21.

8. United States Border Health Commission. Health program for Mexico's northern border. El Paso, Texas: U.S. Border Health Com- mission; 2003. P. 25. Available from: http:// www.borderhealth.org/ Accessed 20 December 2011.

9. United States Border Health Commission. Health program for Mexico's northern border. El Paso, Texas: U.S. Border Health Commission; 2003. P. 11. Available from: http:// www.borderhealth.org/ Accessed 20 December 2011.

10. Lowenstein SR, Yaron M, Carrero R, Devereux D, Jacobs LM. Vertical trauma: injuries to patients who fall and land on their feet. Ann Emerg Med. 1989;18(2):161-5.

11. United States Border Health Commission. Health program for Mexico's northern border. El Paso, Texas: U.S. Border Health Commission; 2003. Pp. 24-30. Available from: http://www.borderhealth.org/ Accessed 20 December 2011.

12. Lewis WS, Lee AL, Grantham SA. "Jumpers syndrome." The trauma of high free fall as seen at Harlem Hospital. J Trauma. 1965;5(6): 812-8.

13. Scalea T, Goldstein A, Phillips T, Sclafani SJ, Panetta T, McAuley J, et al. An analysis of 161 falls from a height: the 'jumper syndrome.' J Trauma. 1986;26(8):706-12.

14. Agalar F, Cakmakci M, Sayek I. Factors effecting mortality in urban vertical free falls: evaluation of 180 cases. Int Surg. 1999;84(3):271-4.

15. Warner KG, Demling RH. The pathophysiology of free-fall injury. Ann Emerg Med. 1986; 15(9):1088-93.
16. Cooper C, Dunham M, Rodriguez A. Falls and major injuries are risk factors for thoracolumbar fractures: cognitive impairment and multiple injuries impede the detection of back pain and tenderness. J Trauma. 1995;38(5):692-6.

17. Durham RM, Luchtefeld WB, Wibbenmeyer L, Maxwell P, Shapiro MJ, Mazuski JE. Evaluation of the thoracic and lumbar spine after blunt trauma. Am J Surg. 1995;170(6):681-5.

18. Reynolds BM, Balsano NA, Reynolds FX. Falls from heights: a surgical experience of 200 consecutive cases. Ann Surg. 1971;174(2):304-8.

19. The Golden Gate Bridge. Available from: http://en.wikipedia.org/wiki/Golden_Gate_ Bridge Accessed 22 December 2011.

20. Bourgault-Côté G. La barrière anti-suicide a prouvé son utilité. Le Devoir.com 2007. Available from: http://www.ledevoir. com/societe/actualites-en-societe/156270/ la-barriere-anti-suicide-a-prouve-son-utilite Accessed 22 December 2011.

21. Prévost C, Julien M, Brown BP. Suicides associated with the Jacques Cartier Bridge, Montreal, Quebec 1988-1993: descriptive analysis and intervention proposal. Can J Public Health. 1996;87(6):377-80.

Manuscript received on 12 August 2011. Revised version accepted for publication on 17 January 2012. 
RESUMEN Objetivo. Comparar la información demográfica y las motivaciones relacionadas con las caídas desde puentes que atraviesan la frontera entre México y los Estados Unidos en el condado de El Paso, Texas; analizar las lesiones y los patrones de le-

Traumatismos por caídas desde puentes que atraviesan la frontera entre México y los Estados Unidos en EI Paso

Palabras clave siones que avalan la intencionalidad; y proporcionar recomendaciones terapéuticas. Métodos. Se llevó a cabo un examen retrospectivo observacional de las internaciones en un centro traumatológico debidas a caídas desde puentes que tuvieron lugar entre 1995 y el 2009. Los métodos estadísticos usados fueron la prueba de ji al cuadrado, la prueba T de comparación de medias, correlaciones de una sola variable y el análisis de regresión.

Resultados. De los 97 pacientes evaluados, 81,4\% cayeron desde puentes ubicados en la frontera México-Estados Unidos, incluido un paciente que cayó desde un puente ferroviario; $74,7 \%$ de las personas que cayeron desde puentes fronterizos tenían un domicilio no residente, en comparación con $22,2 \%$ en las personas que cayeron desde puentes ubicados en el interior de los Estados Unidos. Las caídas desde los puentes fronterizos estaban asociadas con más motivaciones relacionadas con la inmigración y con menos intentos de suicidio. Las lesiones afectaban las extremidades inferiores en 76 pacientes $(78,4 \%)$ y la columna vertebral toracolumbar en $27(27,8 \%)$; 16 pacientes con fractura de la columna toracolumbar $(59,3 \%)$ también presentaban lesión de las extremidades inferiores. La duración media de la hospitalización fue 7,2 días. La puntuación media de gravedad de la lesión fue 8,45 (rango 1 a 43). Una mayor edad, una puntuación alta en la escala de gravedad de la lesión y la fractura pelviana aumentaron la duración de la hospitalización.

Conclusiones. Los pacientes cayeron durante un intento de emigración o inmigración relacionado con la residencia y otros factores motivadores. En 59,3\% de los pacientes con lesión de la columna vertebral toracolumbar esta coexistía con lesión de las extremidades inferiores; al evaluar a pacientes con lesiones por caídas desde puentes se recomienda efectuar estudios de imágenes de la columna vertebral toracolumbar. Las estrategias de prevención propuestas comprenden la colocación de señales en los puentes y la instalación de redes de seguridad.

Fracturas de la columna vertebral; traumatismos encefálicos; migración internacional; accidentes por caídas; salud fronteriza; Estados Unidos; México. 